\title{
Test characteristics of milk amyloid A ELISA, somatic cell count, and bacteriological culture for detection of intramammary pathogens that cause subclinical mastitis
}

\author{
S. Jaeger, ${ }^{*} †$ F. Virchow,† P. R. Torgerson, ${ }^{*}$ M. Bischoff, † B. Biner,† S. Hartnack, ${ }^{* 1}$ and S. R. Rüegg ${ }^{* 1,2}$ \\ ${ }^{*}$ Section of Epidemiology, Vetsuisse Faculty, University of Zurich, Winterthurerstrasse 270, 8057 Zurich, Switzerland \\ †Clinica Alpina SA, Center for Veterinary Medicine, Buorna, 7550 Scuol, Switzerland
}

\begin{abstract}
Bovine mastitis is an important disease in the dairy industry, causing economic losses as a result of withheld milk and treatment costs. Several studies have suggested milk amyloid A (MAA) as a promising biomarker in the diagnosis of mastitis. In the absence of a gold standard for diagnosis of subclinical mastitis, we estimated the diagnostic test accuracy of a commercial MAA-ELISA, somatic cell count (SCC), and bacteriological culture using Bayesian latent class modeling. We divided intramammary infections into 2 classes: those caused by major pathogens (e.g., Escherichia coli, Staphylococcus aureus, streptococci, and lacto-/enterococci) and those caused by all pathogens (major pathogens plus Corynebacterium bovis, coagulase-negative staphylococci, Bacillus spp., Streptomyces spp.). We applied the 3 diagnostic tests to all samples. Of 433 composite milk samples included in this study, $275(63.5 \%)$ contained at least 1 colony of any bacterial species; of those, 56 contained major pathogens and 219 contained minor pathogens. The remaining 158 samples (36.5\%) were sterile. We determined 2 different thresholds for the MAA-ELISA using Bayesian latent class modeling: 3.9 $\mu \mathrm{g} / \mathrm{mL}$ to detect mastitis caused by major pathogens and $1.6 \mu \mathrm{g} / \mathrm{mL}$ to detect mastitis caused by all pathogens. The optimal SCC threshold for identification of subclinical mastitis was 150,000 cells/mL; this threshold led to higher specificity (Sp) than 100,000 cells/ $\mathrm{mL}$. Test accuracy for major-pathogen intramammary infections was as follows: SCC, sensitivity (Se) $92.6 \%$ and Sp 72.9\%; MAA-ELISA, Se $81.4 \%$ and Sp 93.4\%; bacteriological culture, Se $23.8 \%$ and Sp 95.2\%. Test accuracy for all-pathogen intramammary infections was as follows: SCC, sensitivity $90.3 \%$ and Sp $71.8 \%$; MAAELISA, Se $88.0 \%$ and Sp 65.2\%; bacteriological culture,
\end{abstract}

\footnotetext{
Received December 13, 2016.

Accepted May 1, 2017.

${ }^{1}$ These authors contributed equally to project supervision.

${ }^{2}$ Corresponding author: srueegg@vetclinics.uzh.ch
}

Se $83.8 \%$ and Sp 54.8\%. We suggest the use of SCC and MAA-ELISA as a combined screening procedure for situations such as a Staphylococcus aureus control program. With Bayesian latent class analysis, we were able to identify a more differentiated use of the 3 diagnostic tools. The MAA-ELISA is a valuable addition to existing tools for the diagnosis of subclinical mastitis.

Key words: subclinical mastitis, somatic cell count, milk amyloid A, bacteriological culture, Bayesian latent class

\section{INTRODUCTION}

Subclinical mastitis is difficult to detect because of a lack of clinical signs that can be easily identified by visual inspection and palpation of the udder. Reliable diagnostic methods are needed to detect subclinical mastitis. In Swiss veterinary practice, the diagnosis of subclinical mastitis is based on the results of a California Mastitis Test, SCC, or bacteriological culture (BC). However, it has been postulated that the California Mastitis Test and SCC are not sensitive enough to identify subclinical infection, and do not qualify as reliable screening tests (Middleton et al., 2004; Safi et al., 2009). As well, SCC usually remains elevated for several weeks after successful treatment (Pyörälä, 1988) and is affected by many physiological factors, such as age, lactation period, parity, stress, season, and intra- or extramammary infection (Jensen and Eberhart, 1981; Bielfeldt et al., 2004; Sharma et al., 2011). Furthermore, the amplitude of the increase in SCC depends on the pathogen. Minor pathogens (e.g., Corynebacterium bovis, CNS) show less of an effect on SCC than major pathogens (e.g., Escherichia coli, Staphylococcus aureus, Streptococcus dysgalactiae, and Streptococcus uberis; Djabri et al., 2002). To evaluate diagnostic tests for IMI, most recent studies have applied single-sample BC as the gold standard, despite observations that it is affected by contamination and intermittent bacterial shedding, resulting in a low sensitivity (Se; Sears et al., 1990). The suitability of BC as a gold standard has 
been questioned (Grönlund et al., 2005; Andersen et al., 2010) unless 3 consecutive milk samples are used (Dohoo et al., 2011); a referential diagnostic procedure with higher Se and specificity $(\mathbf{S p})$ is desirable.

A promising approach may be to measure the concentration of acute-phase proteins in milk samples. The acute-phase reaction is part of the innate immune system triggered by challenges such as infection, inflammation, or stress (Grönlund et al., 2005). Unlike in humans, dogs, and pigs, where C-reactive protein makes up most acute-phase proteins (Eckersall, 2000; Eckersall et al., 2006), in cattle the major acute-phase proteins are haptoglobin and serum amyloid A (McDonald et al., 2001; Grönlund et al., 2003; Akerstedt et al., 2007; Kovac et al., 2011). An elevated serum concentration of haptoglobin or serum amyloid $\mathrm{A}$ is a nonspecific marker for inflammation anywhere in the animal; it must be present in milk to provide relevant information about udder health (Eckersall et al., 2001). Serum amyloid A migrates passively through the blood-milk-barrier because of the increased permeability of inflamed mammary tissue (Eckersall et al., 2001; Kovac et al., 2011), and it is also locally produced as a particular isoform (M-SAA3) by a restricted population of bovine mammary epithelial cells (McDonald et al., 2001; Gerardi et al., 2009; Molenaar et al., 2009). Serum amyloid A and M-SAA3 together are called milk amyloid A (MAA), which is measurable in milk samples using a commercially available ELISA (Tridelta Development Ltd., Maynooth, Ireland), and MAA has proven to be a reliable biomarker for both subclinical mastitis (Eckersall et al., 2006; Gerardi et al., 2009; Safi et al., 2009; Pyörälä et al., 2011) and clinical mastitis (Molenaar et al., 2009; Kovac et al., 2011; Pyörälä et al., 2011).

As mentioned above, single-sample $\mathrm{BC}$ as a gold standard, with sensitivity $<100 \%$, is ill suited to evaluate the accuracy of new tests, and tends to underestimate their specificity. An alternative approach is to estimate diagnostic accuracy with Bayesian latent class modeling, using results from at least 3 different diagnostic tests of the same sample (Branscum et al., 2005; Berkvens et al., 2006; Hartnack et al., 2013). The aim of this study was to estimate the diagnostic Se and Sp of SCC, MAA-ELISA, and BC for the diagnosis of subclinical mastitis in dairy cows using Bayesian latent class modeling.

\section{MATERIALS AND METHODS}

\section{Animals and Samples}

For the present study, 435 composite milk samples were collected between April and July 2015 as part of a Staph. aureus control program for selected mountain summer pastures in a veterinary practice in Scuol, Switzerland (Clinica Alpina, 5 veterinarians). Only lactating cows with macroscopically healthy udders (i.e., no pathological findings by visual inspection and palpation) were included in the study. All cows from 1 farm that were designated to join the summer mountain pasture program were sampled on the same day. Milk samples were collected aseptically after disinfection of the teat with $70 \%$ alcohol on a cotton ball. The first 3 squirts from each quarter were discarded before milking 1 squirt from each teat into the same sterile tube. Samples were taken during the daily veterinary routine and transported at room temperature for 0.5 to $8 \mathrm{~h}$ (with random distribution) before $\mathrm{BC}$ and $\mathrm{SCC}$ at the laboratory in the veterinary practice. Then, samples were stored at $-18^{\circ} \mathrm{C}$ until the MAA assay was performed. The sampled cows belonged to 39 farms, were in different lactation periods ( 1 to 20 mo after calving, median $6 \mathrm{mo}$ ), and were in different parities (first to eleventh lactation, median second lactation). Cows ranged from 1 to $20 \mathrm{yr}$ of age (median $5.5 \mathrm{yr}$ ).

\section{Laboratory Procedures}

Bacteriological Culture. The BC were performed by 2 laboratory assistants at Clinica Alpina. Approximately $0.01 \mathrm{~mL}$ of each sample was streaked on trypticase soy agar with sheep blood and on MacConkey agar No.3 (MC3; Oxoid, Basingstoke, United Kingdom). Agar plates were evaluated after $24 \mathrm{~h}$ of incubation at $37^{\circ} \mathrm{C}$, and a first suspicion was determined according to the morphological characteristics of the colonies on trypticase soy agar with sheep blood and MC3, as well as by chemical reactions, such as catalase reaction with $\mathrm{H}_{2} \mathrm{O}_{2}$ and Gram stain. Suspicions were confirmed with a second reading $24 \mathrm{~h}$ later. Staphylococci without hemolysis on the trypticase soy agar with sheep blood were classified as CNS, and colonies with $\alpha \beta$ - or only $\beta$-hemolysis were classified as Staph. aureus. Because $\alpha$-hemolytic staphylococci can represent CNS or Staph. aureus, 1 of these colonies was transferred to a chromogen agar (chromID Staph. aureus agar; BioMérieux, Marcy-l'Étoile, France). This agar identifies Staph. aureus using a green coloration of the colonies depending on the production of $\alpha$-glucosidase after 18 to $20 \mathrm{~h}$ of incubation. It has Se of $96.8 \%$ and $\mathrm{Sp}$ of $97.4 \%$ and was set up with a Staph. aureus-positive control (Perry et al., 2003). Only colonies showing the same phenotype as the positive control were classified as Staph. aureus; colonies with a different phenotype were classified as CNS. Streptococci were further classified as Strep. uberis, Strep. dysgalactiae and Strep. agalactiae by esculin reaction (EscTSASB; Oxoid) and using the 
Christie, Atkins, Munch-Petersen phenomenon (Darling, 1975). A selective bile acid agar plate for lacto/ enterococci was employed to distinguish streptococci from lacto-/enterococci (Oxoid); lacto-/enterococci digest the bile acid of the agar, leading to a brown discoloration, but streptococci induce no discoloration. We examined the esculin reaction, the Christie, Atkins, Munch-Petersen phenomenon, and the bile acid agar after $12 \mathrm{~h}$ of incubation. We identified gram-negative pathogens by microscopy of a Gram stain and by indole and oxidase reaction. Cultures with 3 or more different bacterial species were classified as bacteriologically contaminated and excluded from the study.

Somatic Cell Count. We measured SCC using a DeLaval cell counter according to the manufacturer's instructions (Cellcounter DCC; DeLaval, Tumba, Sweden). We aspirated $60 \mu \mathrm{L}$ of sample into a small cassette that contained a DNA-specific fluorescent reagent that bound to the SCC nuclei. The machine counted the fluorescent SCC nuclei in milk using an integrated digital camera.

Milk Amyloid A ELISA. We determined MAA concentrations using a commercial ELISA according to the manufacturer's instructions (Phase Milk Amyloid A; Tridelta Development, Maynooth, Ireland). Optical densities were read on an automatic plate reader (Model ELISA Plate Analyzer; Gentaur, Brussels, Belgium) at $450 \mathrm{~nm}$ and a reference at $630 \mathrm{~nm}$. The MAA concentrations were calculated based on a standard curve using references provided by the manufacturer. Samples were diluted 1:50 and analyzed in duplicate to account for measurement variability and detect inaccuracies in the working process. Because of the detection limits of the test kit at 0.1 and $7.5 \mu \mathrm{g} / \mathrm{mL}$, samples with concentrations beyond $7.5 \mu \mathrm{g} / \mathrm{mL}$ should be further diluted and reanalyzed. However, for this study, it was enough to know that the MAA concentrations were higher than $7.5 \mu \mathrm{g} / \mathrm{mL}$; according to the literature, the cutoff value was expected to be between 0.8 and $7.0 \mu \mathrm{g} / \mathrm{mL}$ (Grönlund et al., 2003; Akerstedt et al., 2011). Therefore, we omitted the dilution step.

\section{Statistical Analysis}

Data were collected in Excel (Microsoft Corp., Redmond, WA), and statistical analysis was conducted in R 3.2.3 (R Core Team, 2015). Bayesian latent class analyses were conducted using JAGS version 4.0.0 (http://mcmc-jags.sourceforge.net/) and the package coda ( $\mathrm{R}$ Core Team, 2015). The $\mathrm{R}$ code for the models is available in Supplemental File S1 (https:// doi.org/10.3168/jds.2016-12446). The SCC values were $\log _{10}$-transformed before analysis. We checked data for missing values and normality, and then computed medians and means. The $\mathrm{BC}$ results were classified into 3 groups to further analyze the effect of pathogen group on MAA and SCC: (1) cultures with at least $100 \mathrm{cfu} /$ $\mathrm{mL}$ of a minor pathogen (CNS, C. bovis, Bacillus spp., or Streptomyces spp.); (2) cultures with at least 1 colony $(100 \mathrm{cfu} / \mathrm{mL})$ of a major pathogen (E. coli, Staph. aureus, Strep. uberis, or lacto-/enterococci; Djabri et al., 2002; Gillespie et al., 2009); and (3) sterile samples. We used ANOVA with Tukey's honest significance difference method to examine the difference in SCC between samples with minor pathogens, samples with major pathogens, and sterile samples. We investigated the same question for MAA using the Kruskal-Wallis test with post hoc Dunn's test, because the data were not normally distributed. We investigated the effects of age, lactation period, and parity on SCC and MAA concentration using a linear mixed effects model, including the adjustment for clustering at the farm level. Statistical significance was considered at $P<0.05$ for all tests.

\section{Bayesian Latent Class Analysis}

We estimated diagnostic test accuracy for BC, SCC, and MAA-ELISA using Bayesian latent class analysis. For a detailed model description, see Lewis and Torgerson (2012). Diagnostic Se was defined as the probability that a test would correctly classify true positive samples; diagnostic Sp was defined as the probability that a test would correctly classify true negative samples. For BC, we used the categories "all pathogens" and "major pathogens" (Table 1) to account for the dependence of Se and Sp on defining a positive culture (Dohoo et al., 2011; Reyher and Dohoo, 2011). We investigated 2 basic latent class models and used initial analyses with non-informative priors as $\beta$ distributions $(1,1)$ for all parameters of both models, as described by Lewis and Torgerson (2012). We set thresholds for SCC and MAA-ELISA at 100,000 cells $/ \mathrm{mL}$ and at 1 $\mu \mathrm{g} / \mathrm{mL}$, respectively, for both models. We evaluated conditional dependences between the tests by investigating the influence of each covariance term separately. We considered the following 3 pairs of covariance terms for Se and Sp: (1) SCC and MAA-ELISA, (2) SCC and $\mathrm{BC}$, and (3) MAA-ELISA and BC. We included each covariance term in both basic models, first one by one and then 2 terms together. We identified influential covariances by considering the histograms of their posteriors: if the most frequent posterior was at $x=0$, covariance was considered negligible; in all other cases, it was influential. We specified the best-fitting models for both mastitis definitions based on the deviance in- 
Table 1. Definitions for culture-positive/mastitis-positive ${ }^{1}$

\begin{tabular}{ll}
\hline Classification & Definition \\
\hline All pathogens & At least 1 colony $(100 \mathrm{cfu} / \mathrm{mL})$ of any species was detectable on the trypticase soy agar with sheep blood or on \\
Major pathogens & MacConkey agar no. 3 \\
& At least 1 single colony $(100 \mathrm{cfu} / \mathrm{mL})$ of a major pathogen was detectable on the trypticase soy agar with sheep \\
& blood on MacConkey agar no. 3
\end{tabular}

${ }^{1}$ Cultures showing only minor pathogens were classified as mastitis-negative.

formation criteria (Spiegelhalter et al., 2002) for the models, with the influential covariance terms included. The structures of the best-fitting Bayesian latent class models, including covariances between tests, are shown in Table 2 for both $\mathrm{BC}$ definitions. Histograms of the posteriors of all influential covariance terms, as well as test accuracy and deviance information criterion values for the alternative models, which include all different combinations of covariances, are reported in the supplementary documentation [Supplemental Figures S1 to S4 (see Supplemental File S2) and Supplemental Table S1 (see Supplemental File S3), respectively; https://doi. org/10.3168/jds.2016-12446]. Considering more than 2 covariance terms in a model resulted in very wide confidence intervals for the posteriors, indicating that these models were not identifiable. We also performed a sensitivity analysis to check the influence of informative priors on posteriors [Supplemental Figures S5 to S46 (see Supplemental File S4); https://doi.org/10.3168/ jds.2016-12446].

By means of the best-fitting Bayesian latent class models, we assessed the optimal cutoffs for MAA-ELISA and SCC. Both models were computed first with 70 equidistant cutoff values for MAA between 0 and 7.0 $\mu \mathrm{g} / \mathrm{mL}$. Then, we performed the same procedure for SCC, considering 20 equidistant cutoff values between 25,000 and 2,000,000 cells/mL. We identified the optimal cutoffs for SCC and MAA using receiver operating characteristic curves and a Youden analysis according to Fluss et al. (2005).

For each Bayesian latent class analysis, we rejected the first 20,000 iterations were rejected as burn-in and used the following 50,000 iterations for parameterization of the models. We ran 3 chains from 3 different starting points as used by Hartnack et al. (2013) and screened for convergence.

\section{RESULTS}

Of 435 collected milk samples, 2 were excluded because of bacterial contamination. Of the remaining 433 cultures, $275(63.5 \%)$ showed growth of at least 1 colony of any species after $48 \mathrm{~h}$ of incubation, and 158 (36.5\%) were considered sterile. Of the 275 BC-positive samples, $219(79.6 \%)$ contained only minor pathogens and in $56(20.4 \%)$ contained major pathogens. We identified a monoculture in 225 samples, and detected the growth of 2 different bacterial species in 48 cultures. The most common isolated pathogen was C. bovis, followed by CNS and Staph. aureus. Other isolated pathogens were Strep. uberis, Strep. dysgalactiae, lacto-/enterococci, E. coli, Bacillus spp., and Streptomyces spp. (Table 3). The MAA concentrations and the $\log _{10} \mathrm{SCC}$ were significantly different between samples with major pathogens and samples with only minor pathogens or sterile samples; they were also significantly different between samples with minor pathogens and sterile samples (all $P<0.01$; Figure 1; Table 3). We found no significant effect of age, lactation period, or lactation number on SCC, MAA concentration, or BC results $(P>0.05)$.

The optimal threshold for SCC was 150,000 cells $/ \mathrm{mL}$ for both BC categories, resulting in 254/433 (58.7\%) samples with increased SCC. Using the conventional SCC cutoff of 100,000 cells $/ \mathrm{mL}$ to detect subclinical mastitis in composite samples (Bludau et al., 2014), 298/433 (68.8\%) had an elevated SCC.

Using the best MAA thresholds identified by Bayesian latent class analysis at $1.6 \mu \mathrm{g} / \mathrm{mL}$ (all pathogens) and $3.9 \mu \mathrm{g} / \mathrm{mL}$ (major pathogen), 266/433 (61.4\%) and $180 / 433(41.6 \%)$ samples, respectively, were positive for subclinical mastitis. Applying the cutoff of 1 $\mu \mathrm{g} / \mathrm{mL}$ suggested by other authors (Akerstedt et al., 2011; Crosson et al., 2015), 312/433 (72.1\%) samples

Table 2. Structure of the 2 applied Bayesian models ${ }^{1}$

\begin{tabular}{lll}
\hline BC interpretation & Covariance 1 & Covariance 2 \\
\hline All pathogens & Specificity (Sp) of SCC with Sp of MAA & Sp of MAA with Sp of BC \\
Major pathogens & Sensitivity (Se) of SCC with Se of MAA & Sp of SCC with Sp of MAA \\
\hline${ }^{1}$ BC = bacteriological culture; MAA = milk amyloid A. &
\end{tabular}


Table 3. Number of samples containing major, minor, or no pathogens, with corresponding milk amyloid A (MAA) concentration and $\log _{10} \mathrm{SCC}$

\begin{tabular}{lccc}
\hline Bacteria & $\mathrm{n}$ & $\begin{array}{c}\text { Median MAA, } \mu \mathrm{g} / \mathrm{mL} \\
(0.025,0.975)\end{array}$ & $\begin{array}{c}\text { Median } \log _{10} \mathrm{SCC} \text { cells } / \mathrm{mL} \\
(0.025,0.975)\end{array}$ \\
\hline $\begin{array}{l}\text { Major pathogen } \\
\quad \text { Staphylococcus aureus }\end{array}$ & 26 & $8.19(1.52,49.85)$ & $5.91(5.20,6.40)$ \\
Streptococcus uberis & 14 & $6.27(0.28,30.01)$ & $5.49(4.83,6.11)$ \\
Other & 16 & $5.19(0.19,14.78)$ & $5.47(4.21,6.49)$ \\
$\quad$ Total & 56 & $6.68(0.16,41.87)$ & $5.66(4.39,6.45)$ \\
Minor pathogen & & & \\
CNS & 76 & $3.24(0,13.71)$ & $5.25(4.29,6.01)$ \\
Corynebacterium bovis & 109 & $3.63(0,14.75)$ & $5.38(4.48,5.98)$ \\
CNS and C. bovis & 28 & $3.60(0,16.19)$ & $5.41(4.32,5.97)$ \\
Other & 6 & $1.40(0.42,5.16)$ & $5.79(4.03,5.52)$ \\
$\quad$ Total & 219 & $3.44(0,14.68)$ & $5.37(4.25,6.02)$ \\
Sterile (no growth) & 158 & $1.28(0,14.75)$ & $5.04(4.00,5.91)$ \\
\hline
\end{tabular}

were positive for subclinical mastitis. The estimated test accuracies for the different cutoff values are shown in Table 4 [density distributions of Se and Sp in Supplemental Figures S47 and S48 (see Supplemental File S5); https://doi.org/10.3168/jds.2016-12446]. Receiver operating characteristic curves for the 70 MAA thresholds and the 20 SCC thresholds can be found in Supplemental Figures S49 and S50 (see Supplemental File S6; https://doi.org/10.3168/jds.2016-12446).

\section{DISCUSSION}

We suggest cutoff values of $3.9 \mu \mathrm{g} / \mathrm{mL}$ for the MAAELISA to detect mastitis from major pathogens and $1.6 \mu \mathrm{g} / \mathrm{mL}$ to detect mastitis from all pathogens when working with defrosted milk samples. A previous study suggested a cutoff of $1 \mu \mathrm{g} / \mathrm{mL}$, because none of the collected quarter milk samples from clinically healthy cattle exceeded that value (Akerstedt et al., 2011).
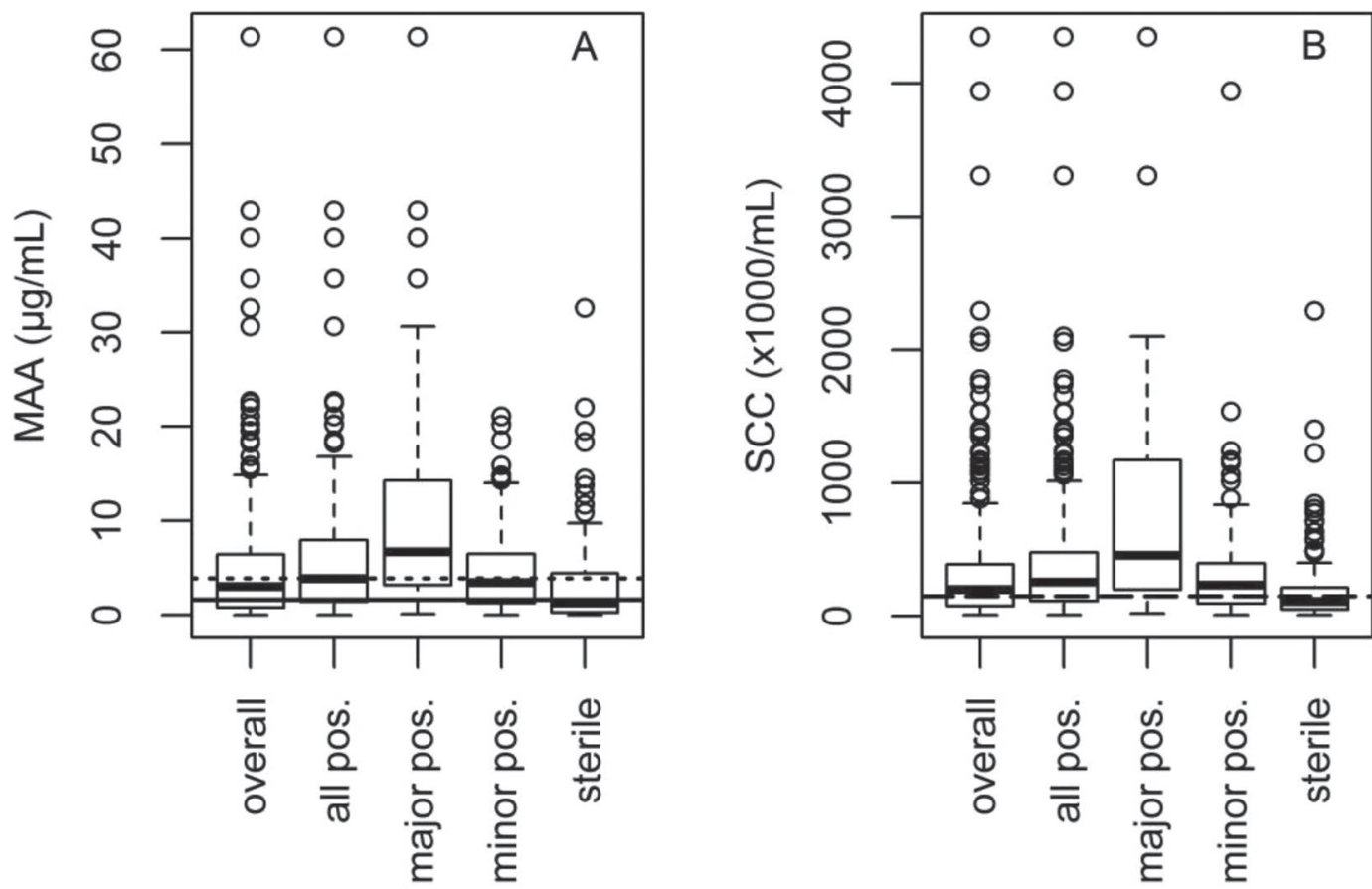

Figure 1. (A) Milk amyloid A (MAA) concentration, and (B) SCC overall and in the different bacteriological culture classes. The solid black line refers to the median, the box extends from the first to the third quartile, the whiskers show values within 1.5 times the interquartile range from the box, and the dots show more extreme values. All pos = all samples classified as positive with either major or minor pathogens; major pos $=$ samples classified as positive with only a major pathogen; minor pos = samples classified as positive with only a minor pathogen; sterile $=$ no bacterial growth. The best threshold for the MAA-ELISA was $1.6 \mu \mathrm{g} / \mathrm{mL}$ to detect IMM caused by all pathogens (solid line) and $3.9 \mu \mathrm{g} /$ $\mathrm{mL}$ (dotted line) to detect IMI caused by major pathogens. The best threshold for SCC was 150,000 cells/mL for both classes (dashed line). 


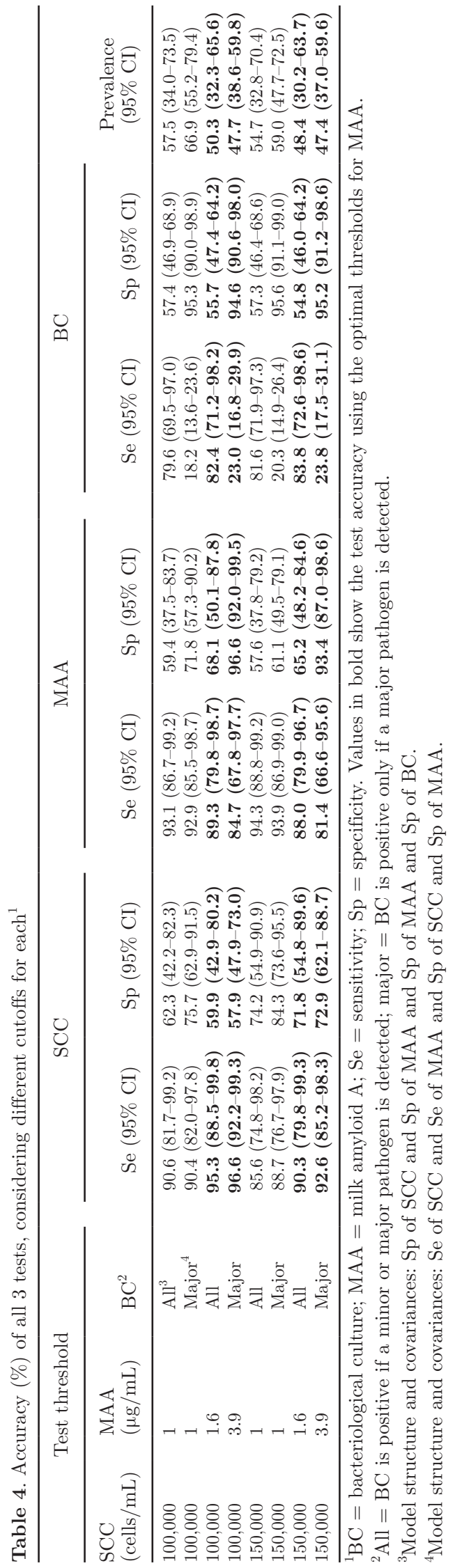

However, that study had a very low sample size of only 10 clinically healthy cattle, and the recommended cutoff came from the observation that 8 of the 10 controls had readings below $1 \mu \mathrm{g} / \mathrm{mL}$; it did not include a Bayesian latent class approach or receiver operating characteristic curves for estimation of the cutoff. Our data suggest that preselection of healthy cattle with SCC $<100,000$ cells/mL yields lower MAA concentrations without discriminating for subclinical mastitis. A recent study applied the same threshold of $1 \mu \mathrm{g} / \mathrm{mL}$ to explore whether MAA was suitable as a biomarker for udder health status in cattle before drying off (Crosson et al., 2015). The authors observed the same Se for the MAA-ELISA (94.5\%) as we did (94.3\%) using similar thresholds (BC all pathogens, SCC cutoff 150,000 cells/ $\mathrm{mL}$, and MAA cutoff $1 \mu \mathrm{g} / \mathrm{mL}$ ). However, their estimate for $\mathrm{Sp}(93.0 \%)$ was much higher than ours $(57.6 \%)$. Their gold standard was based on BC of quarter milk samples, which were positive with $\geq 100 \mathrm{cfu} / \mathrm{mL}$ of any pathogen, except for CNS, for which $\geq 200 \mathrm{cfu} / \mathrm{mL}$ was considered positive. Their high Sp can be explained by their more stringent interpretation of cultures with CNS, compared with our "all pathogens" interpretation, as well as because their statistical approach ignored the latent nature of subclinical inflammation (Dohoo et al., 2011). Another study reported that the best threshold for MAA was $13.43 \mu \mathrm{g} / \mathrm{mL}$, resulting in $100 \%$ Se and $100 \%$ Sp using clinical mastitis as the gold standard (Haghkhah et al., 2010). In general, measuring mastitis indicators in samples from cows with clinical mastitis is redundant, because the clinical signs are pathognomonic. This approach leads to a highly overestimated performance of the MAA-ELISA, and this threshold has not been confirmed elsewhere.

To identify IMI with any possible pathogen, we suggest an optimal SCC threshold of 150,000 cells/mL. The determined test accuracies for SCC in this study (Table 4) were in agreement with McDermott et al. (1982), who reported Se of $92 \%$ and $\mathrm{Sp}$ of $53 \%$ at a threshold of 100,000 cells/mL. Using a higher threshold of 200,000 cells/mL, they reported Se of $89 \%$ and $\mathrm{Sp}$ of $75 \%$ for subclinical mastitis. Their study population consisted of 719 lactating Holstein and Brown Swiss cows in different lactations and lactation periods. They applied BC as the gold standard and diagnosed mastitis if at least 1 colony of a major pathogen was detected. The $95 \%$ confidence intervals we found for the Se and Sp of SCC for mastitis from major pathogens (Table 4) include their estimates. Another study used $\mathrm{BC}$ results of triplicate samples as the gold standard and reported similar performance data to ours for SCC (Se $72.6 \%$ and Sp $85.5 \%$ for mastitis from all pathogens; Se $83.4 \%$ and Sp $58.9 \%$ for mastitis from major pathogens; Dohoo and Leslie, 1991). Pepe and Janes 
(2007) emphasized that Bayesian latent class analysis often proceeds without a formal clinical definition of disease, leading to prevalence and test accuracy parameters that are not well defined. However, for subclinical mastitis, clinical symptoms are absent and diagnosis relies entirely on laboratory results; in the absence of a gold-standard test, this approach remains the most realistic for estimating test accuracy. The choice of 1 good informative prior is difficult, because the relevant literature on cutoffs for SCC and BC is very heterogeneous. Our sensitivity analysis, which used several different informative priors based on a $\beta$ distribution, indicated that the posterior estimates remained unaffected by a wide range of plausible informative priors [Supplemental Figures S5 to S46 (see Supplemental File S4); https://doi.org/10.3168/jds.2016-12446].

We did not detect a significant difference in test accuracy between SCC and MAA-ELISA, suggesting that both were equally important nonspecific mastitis indicators. Because both tests were based on different physiological factors, the results required confirmation with BC. According to Sears et al. (1990), this approach required 3 consecutive milk samples to reach $98 \% \mathrm{Se}$ for detecting major pathogens, especially Staph. aureus. For proper reading, each culture must be incubated for at least $24 \mathrm{~h}$, entailing a significant loss of time before mastitis-negative animals can be dismissed. We suggest the use of SCC and MAA-ELISA as a combined screening procedure for IMI caused by major pathogens. As a first step, SCC (cutoff 100,000 cells/mL), with its high diagnostic Se of $96.6 \%$, can be used to detect all udders that are potentially infected with major pathogens. Then, the MAA-ELISA (cutoff $3.9 \mu \mathrm{g} / \mathrm{mL}$ ), with its high Sp of 96.6\%, can be performed on all SCC-positive samples. This test sequence could produce reliable outcomes in a very short time and result in an overall Se of $82 \%$ and a Sp of $98 \%$ to detect mastitis caused by major pathogens. Consecutive BC allows for determination of the proper antibiotic for treatment. Because IMI from minor pathogens have a high self-healing potential, BC can be spared in all cases that are negative for SCC and MAA. It is important to note that all diagnostic test performances are population-specific, leading to a spectrum bias. Thus, a careful description of the underlying population is needed (Lijmer et al., 1999; Sackett and Haynes, 2002).

This study evaluated the recently developed MAAELISA as a new method for diagnosing subclinical mastitis. To our knowledge, it is the first report on the use of Bayesian latent class modeling to evaluate SCC, MAA-ELISA, and BC simultaneously for the detection of subclinical mastitis. With this holistic evaluation, we identified a differentiated way to use these 3 diagnostic tools in combination. The MAA-ELISA is a valuable addition to existing tools, and its practical applicability would be further enhanced if it were a cow-side test kit.

\section{ACKNOWLEDGMENTS}

This study was funded by the Section of Veterinary Epidemiology at the Vetsuisse Faculty of the University of Zurich and by the Clinica Alpina in Scuol.

\section{REFERENCES}

Akerstedt, M., L. Forsbäck, T. Larsen, and K. Svennersten-Sjaunja. 2011. Natural variation in biomarkers indicating mastitis in healthy cows. J. Dairy Res. 78:88-96. https://doi.org/10.1017/ S0022029910000786.

Akerstedt, M., K. Persson Waller, and A. Sternesjö. 2007. Haptoglobin and serum amyloid $\mathrm{A}$ in relation to the somatic cell count in quarter, cow composite and bulk tank milk samples. J. Dairy Res. 74:198-203. https://doi.org/10.1017/S0022029906002305.

Andersen, S., I. R. Dohoo, R. Olde Riekerink, and H. Stryhn. 2010 Diagnosing intramammary infections: Evaluating expert opinions on the definition of intramammary infection using conjoint analysis. J. Dairy Sci. 93:2966-2975. https://doi.org/10.3168/jds.20092726.

Berkvens, D., N. Speybroeck, N. Praet, A. Adel, and E. Lesaffre. 2006. Estimating disease prevalence in a Bayesian framework using probabilistic constraints. Epidemiology. 17:145-153. https://doi. org/10.1097/01.ede.0000198422.64801.8d.

Bielfeldt, J. C., R. Badertscher, K. H. Tölle, and J. Krieter. 2004 Factors influencing somatic cell score in Swiss dairy production systems. Schweiz. Arch. Tierheilkd. 146:555-560. https://doi. org/10.1024/0036-7281.146.12.555.

Bludau, M. J., A. Maeschli, F. Leiber, A. Steiner, and P. Klocke. 2014. Mastitis in dairy heifers: Prevalence and risk factors. Vet. J. 202:566-572. https://doi.org/10.1016/j.tvj1.2014.09.021.

Branscum, A. J., I. A. Gardner, and W. O. Johnson. 2005. Estimation of diagnostic-test sensitivity and specificity through Bayesian modeling. Prev. Vet. Med. 68:145-163. https://doi.org/10.1016/j. prevetmed.2004.12.005.

Crosson, C., L. Mériaux, T. Decers, and M. Belvalette. 2015. A screening method using milk amyloid A measurement in cow milk to significantly reduce the use of intramammary antibiotics at drying off. ICAR Tech. Ser. 9:35-43.

Darling, C. L. 1975. Standardization and evaluation of the CAMP reaction for the prompt, presumptive identification of Streptococcus agalactiae (Lancefield group B) in clinical material. J. Clin. Microbiol. 1:171-174.

Djabri, B., N. Bareille, F. Beaudeau, and H. Seegers. 2002. Quarter milk somatic cell count in infected dairy cows: A meta-analysis. Vet. Res. 33:335-357. https://doi.org/10.1051/vetres:2002021.

Dohoo, I. R., and K. E. Leslie. 1991. Evaluation of changes in somatic cell counts as indicators of new intramammary infections. Prev. Vet. Med. 10:225-237. https://doi.org/10.1016/01675877(91)90006-N.

Dohoo, I. R., J. Smith, S. Andersen, D. F. Kelton, and S. Godden. 2011. Diagnosing intramammary infections: Evaluation of definitions based on a single milk sample. J. Dairy Sci. 94:250-261. https://doi.org/10.3168/jds.2010-3559.

Eckersall, P. 2000. Recent advances and future prospects for the use of acute phase proteins as markers of disease in animals. Rev. Med. Vet. (Toulouse) 151:577-584.

Eckersall, P. D., F. J. Young, A. M. Nolan, C. H. Knight, C. McComb, M. M. Waterston, C. J. Hogarth, E. M. Scott, and J. L. Fitzpatrick. 2006. Acute phase proteins in bovine milk in an experimental model of Staphylococcus aureus subclinical mastitis. J. Dairy Sci. 89:1488-1501. https://doi.org/10.3168/jds.S0022-0302(06)722160 . 
Eckersall, P. D., F. J. Young, C. McComb, C. J. Hogarth, S. Safi, J. L. Fitzpatrick, A. M. Nolan, A. Weber, and T. McDonald. 2001. Acute phase proteins in serum and milk from dairy cows with clinical mastitis. Vet. Rec. 148:35-41. https://doi.org/10.1136/ vr.148.2.35.

Fluss, R., D. Faraggi, and B. Reiser. 2005. Estimation of the Youden Index and its associated cutoff point. Biom. J. 47:458-472. https:// doi.org/10.1002/bimj.200410135.

Gerardi, G., D. Bernardini, C. Azzurra Elia, V. Ferrari, L. Iob, and S. Segato. 2009. Use of serum amyloid A and milk amyloid A in the diagnosis of subclinical mastitis in dairy cows. J. Dairy Res. 76:411-417. https://doi.org/10.1017/S0022029909990057.

Gillespie, B. E., S. I. Headrick, S. Boonyayatra, and S. P. Oliver. 2009 Prevalence and persistence of coagulase-negative Staphylococcus species in three dairy research herds. Vet. Microbiol. 134:65-72. https://doi.org/10.1016/j.vetmic.2008.09.007.

Grönlund, U., C. Hallén Sandergren, and K. Persson Waller. 2005. Haptoglobin and serum amyloid A in milk from dairy cows with chronic sub-clinical mastitis. Vet. Res. 36:191-198. https://doi. org/10.1051/vetres:2004063.

Grönlund, U., C. Hultén, P. D. Eckersall, C. Hogarth, and K. Persson Waller. 2003. Haptoglobin and serum amyloid A in milk and serum during acute and chronic experimentally induced Staphylococcus aureus mastitis. J. Dairy Res. 70:379-386. https://doi. org/10.1017/S0022029903006484.

Haghkhah, M., S. Nazifi, and G. Jahromi. 2010. Evaluation of milk haptoglobin and amyloid A in high producing dairy cattle with clinical and subclinical mastitis in Shiraz. Comp. Clin. Pathol. 19:547-552. https://doi.org/10.1007/s00580-009-0919-3.

Hartnack, S., C. M. Budke, P. S. Craig, Q. Jiamin, B. Boufana, M. Campos-Ponce, and P. R. Torgerson. 2013. Latent-class methods to evaluate diagnostics tests for Echinococcus infections in dogs. PLoS Negl. Trop. Dis. 7:e2068. https://doi.org/10.1371/journal. pntd.0002068.

Jensen, D. L., and R. J. Eberhart. 1981. Total and differential cell counts in secretions of the nonlactating bovine mammary gland. Am. J. Vet. Res. 42:743-747.

Kovac, G., C. Tothova, O. Nagy, and H. Seidel. 2011. Milk amyloid A and selected serum proteins in cows suffering from mastitis. Acta Vet. Brno 80:3-9. https://doi.org/10.2754/avb201180010003.

Lewis, F. I., and P. R. Torgerson. 2012. A tutorial in estimating the prevalence of disease in humans and animals in the absence of a gold standard diagnostic. Emerg. Themes Epidemiol. 9:9. https:// doi.org/10.1186/1742-7622-9-9.

Lijmer, J. G., B. W. Mol, S. Heisterkamp, G. J. Bonsel, M. H Prins, J. H. P. Van der Meulen, and P. M. M. Bossuyt. 1999. Empirical evidence of design-related bias in studies of diagnostic tests. JAMA 282:1061-1066. https://doi.org/10.1001/ jama.1995.03520290060030.

McDermott, M. P., H. N. Erb, and R. P. Natzke. 1982. Predictability by somatic cell counts related to prevalence of intrammary infection within herds. J. Dairy Sci. 65:1535-1539. https://doi. org/10.3168/jds.S0022-0302(82)82378-3.

McDonald, T. L., M. A. Larson, D. R. Mack, and A. Weber. 2001. Elevated extrahepatic expression and secretion of mammaryassociated serum amyloid A 3 (M-SAA3) into colostrum. Vet.
Immunol. Immunopathol. 83:203-211. https://doi.org/10.1016/ S0165-2427(01)00380-4.

Middleton, J. R., D. Hardin, B. Steevens, R. Randle, and J. W. Tyler. 2004. Use of somatic cell counts and California mastitis test results from individual quarter milk samples to detect subclinical intramammary infection in dairy cattle from a herd with a high bulk tank somatic cell count. J. Am. Vet. Med. Assoc. 224:419-423. https://doi.org/10.2460/javma.2004.224.419.

Molenaar, A. J., D. P. Harris, G. H. Rajan, M. L. Pearson, M. R. Callaghan, L. Sommer, V. C. Farr, K. E. Oden, M. C. Miles, R. S Petrova, L. L. Good, K. Singh, R. D. McLaren, C. G. Prosser, K. S. Kim, R. J. Wieliczko, M. H. Dines, K. M. Johannessen, M. R. Grigor, S. R. Davis, and K. Stelwagen. 2009. The acute-phase protein serum amyloid A3 is expressed in the bovine mammary gland and plays a role in host defence. Biomarkers 14:26-37. https://doi. org/10.1080/13547500902730714.

Pepe, M. S., and H. Janes. 2007. Insights into latent class analysis of diagnostic test performance. Biostatistics 8:474-484. https://doi. org/10.1093/biostatistics/kx1038.

Perry, J. D., C. Rennison, L. A. Butterworth, A. L. J. Hopley, and F. K. Gould. 2003. Evaluation of S. aureus ID, a new chromogenic agar medium for detection of Staphylococcus aureus. J. Clin. Microbiol. 41:5695-5698. https://doi.org/10.1128/JCM.41.12.569555698.2003.

Pyörälä, S. 1988. Indicators of inflammation to evaluate the recovery from acute bovine mastitis. Res. Vet. Sci. 45:166-169.

Pyörälä, S., M. Hovinen, H. Simojoki, J. Fitzpatrick, P. D. Eckersall, and T. Orro. 2011. Acute phase proteins in milk in naturally acquired bovine mastitis caused by different pathogens. Vet. Rec. 168:535 https://doi.org/10.1136/vr.d1120.

R Core Team. 2015. R: A Language and Environment for Statistical Computing. R Foundation for Statistical Computing, Vienna, Austria.

Reyher, K. K., and I. R. Dohoo. 2011. Diagnosing intramammary infections: Evaluation of composite milk samples to detect intramammary infections. J. Dairy Sci. 94:3387-3396. https://doi. org $/ 10.3168 /$ jds.2010-3907.

Sackett, D. L., and R. B. Haynes. 2002. The architecture of diagnostic research. BMJ 324:539-541. https://doi.org/10.1136/ bmj.324.7337.602.

Safi, S., A. Khoshvaghti, S. R. Jafarzadeh, M. Bolourchi, and I. Nowrouzian. 2009. Acute phase proteins in the diagnosis of bovine subclinical mastitis. Vet. Clin. Pathol. 38:471-476. https://doi. org/10.1111/j.1939-165X.2009.00156.x.

Sears, P. M. B. S. Smith, P. B. English, P. S. Herer, and R. N. Gonzalez. 1990. Shedding pattern of Staphylococcus aureus from bovine intramammary infections. J. Dairy Sci. 73:2785-2789. https://doi. org/10.3168/jds.S0022-0302(90)78964-3.

Sharma, N., N. K. Singh, and M. S. Bhadwal. 2011. Relationship of somatic cell count and mastitis: An overview. Asian-australas. J. Anim. Sci. 24:429-438. https://doi.org/10.5713/ajas.2011.10233.

Spiegelhalter, D. J., N. G. Best, B. P. Carlin, and A. Van Der Linde. 2002. Bayesian measures of model complexity and fit. J. R. Stat. Soc. Series B Stat. Methodol. 64:583-616. https://doi. org/10.1111/1467-9868.00353. 